\title{
COST EFFICIENCY MEASUREMENT USING TWO-STAGE DATA ENVELOPMENT ANALYSIS IN THE CZECH AND SLOVAK BANKING SECTORS*
}

\author{
Iveta PALECKOVA \\ (Received: 9 November 2017; revision received: 3 August 2018; \\ accepted: 16 August 2018)
}

The aim of the paper is to estimate cost efficiency and its determinants of the Czech and Slovak commercial banks within the period of 2005-2015. In this paper two-stage Data Envelopment Analysis (DEA) is used. In the first stage, I estimate the relative cost efficiency applying the inputoriented model with variable return to scale and find that the Czech banks were more cost efficient than the Slovak banks. The main reason of cost inefficiency is the excess of clients' deposits in the banks' balance sheet. In the second stage, I use the panel data analysis and estimate the determinants of cost efficiency in the two countries. I choose 8 bank-specific and macroeconomic factors that influence cost efficiency. The results show that the larger banks with higher liquidity risk and with a lower value of the net interest margin were more efficient. It confirms the reason of inefficiency determined from the DEA model. Banks were highly cost efficient during the economic expansion with a lower value of the inflation rate.

Keywords: commercial bank, cost efficiency, Czech Republic, Data Envelopment Analysis, efficiency determinants, panel data analysis, Slovakia

JEL classification indices: G21, C14

* Research behind this paper was supported by the Czech Science Foundation within the project No. GAČR 16-17796S: "Affiliation with financial conglomerate as a determinant of performance and risk of banks".

Iveta Palečková, Assistant Professor at Silesian University, School of Business Administration, Department of Finance and Accounting, Karviná, Czech Republic. E-mail: paleckova@opf.slu.cz 


\section{INTRODUCTION}

The reason for exploring banking performance of the Czech and Slovak banking sectors is its importance and dominant role in the provision of intermediate services and the capital formation process. The two countries have primarily bankbased financial systems, and commercial banks play a key role in the development of financial system and economy. Therefore, the examination of efficiency of these banks is an important topic. The paper deals with the determinants of banking efficiency and also with how bank managers can influence it.

Daraio - Simar (2007) defined efficiency as a distance between the quantity of input and output, which defines a frontier, the best possible frontier for a firm in its cluster (industry). In the empirical literature two major approaches are used for estimation of banking efficiency, the parametric and non-parametric approach. The non-parametric (mathematical programming) approach is represented mainly by the Data Envelopment Analysis (DEA) and the Free Disposal Hull method, while the parametric (econometric) approach is represented by the Stochastic Frontier Analysis (SFA) and the Thick Frontier Analysis. Stavárek Polouček (2004) stated that both approaches use different techniques to envelop a data set with different assumptions for random noise and for the structure of production technology. These assumptions generate strengths and drawbacks for both approaches that can be grouped under two categories.

In the literature there is no consensus about the most suitable method between the parametric and non-parametric one to measure efficiency. The choice of estimation technique has attracted debate since no method is strictly preferable to one (Murillo-Zamorano 2004). Several authors compared banking efficiency using two methods (e.g. Casu et al. 2004). As Ariff - Can (2008) mentioned the DEAbased technique worked well with a small sample size and did not require knowledge of any functional form of the frontier. Following this, it becomes important to examine the Czech and Slovak commercial banks due to its small number.

The aim of the paper is to estimate cost efficiency and its determinants of the Czech and Slovak commercial banks within the period of 2005-2015. I used a two-stage DEA model. In the first stage, I estimated the cost efficiency while in the second stage, I used panel data analysis to estimate the determinants of cost efficiency.

The structure of the paper is following: Section 2 presents the literature review regarding cost efficiency in the Czech and Slovak banking sectors. Section 3 describes the methodology and variables used. In Section 4, the empirical analysis and results are presented. Section 5 concludes with the main results of the paper. 


\section{LITERATURE REVIEW}

\subsection{Cost efficiency in the Czech and Slovak banking sectors}

The cost efficiency of banks can be examined using parametrical and non-parametrical methods. Rossi et al. (2005) examined the cost and profit efficiency level of banks in 9 Central and Eastern Europe (CEE) countries ${ }^{1}$, providing cross-country and time series evidence on the period of 1995-2002. A SFA method was used and the results indicated a generally low level of cost efficiency. Researchers also found significant differences among countries and some evidence of an increasing tendency over time in cost efficiency. Fries - Taci (2005) examined the cost efficiency of 15 transition countries using the SFA method. The study showed that the most efficient banking sectors were in Estonia, Lithuania, Kazakhstan, Slovakia, Slovenia and the least efficient were banking sectors in Bulgaria, the Czech Republic, Russia and Romania.

Weill (2007) compared the cost efficiency of banks from western European countries and CEE countries (Czech Republic, Hungary, Latvia, Poland, Slovenia and Slovakia) during the years 1996-2000. He found that CEE banks were less efficient than Western European ones. From the CEE countries the most efficient were the Hungarian and Czech banking sectors and the lowest efficient was the banking sector in Slovakia. Staněk (2010) compared the Czech Republic and Austria applying the SFA method and found that the efficiency of the Czech banking sector has improved in the last 10 years and got closer to Austria.

Irsova - Havranek (2011) compared five CEE countries (Czech Republic, Hungary, Poland, Slovenia, Slovakia) in the years 1995-2006. They used a special model of SFA method and found the highest average cost efficiency in Slovenian and Czech banking sectors and the lowest efficiency in the Slovak banking sector. Andries - Căpraru (2011) measured the cost efficiency using the SFA method in 17 CEE countries for the 2004-2008 period. Their results showed that the highest level of technical efficiency was recorded in the banking systems of the Czech Republic, Hungary and Croatia. Besides this, the average cost efficiency of banks in the CEE countries grew in the analysed period.

Relatively new studies examined the cost efficiency of the banking sectors using non-parametric methods. For example, Chronopoulos et al. (2011) examined the cost and profit efficiency of $10 \mathrm{CEE}$ countries which included the Czech and Slovak banking sectors using the DEA models and found that the banks suffered from relatively high cost inefficiencies and that there were noticeable dif-

Czech Republic, Estonia, Hungary, Latvia, Lithuania, Poland, Romania, Slovakia and Slovenia. 
ferences in the efficiency levels across the countries. Pančurová - Lyócsa (2013) estimated bank efficiencies and their determinants for the sample of $11 \mathrm{CEE}$ countries (including the Czech Republic and Slovakia). They also used the DEA model and showed that the average cost efficiency was the highest for the Czech banking sectors and the cost efficiency was decreasing, on average, during the 2005-2008 period.

Kočišová (2014) estimated cost, revenue and profit efficiency of the Czech and Slovak banking sector using the DEA model within the period of 2009-2013, as well. Results showed that the Czech commercial banks were more cost efficient than the Slovak ones during the period analysed. Zimková (2015) employed both the traditional and new approach of the DEA method to measure cost efficiency of 15 Slovak banking institutions. Her findings showed that using the traditional approach and assuming that the input prices are exogenously given, the transformation of human sources and deposits into loans were successfully achieved by four banking institutions, while with a new measure that allows endogeneity of the input prices, this was successfully achieved by 8 banks. Also Zimková Bod'a (2015) applied the DEA approach to examine cost efficiency of the Slovak banking sector in 2012. Their results showed that the most cost efficient were the two largest Slovak commercial banks.

Though there are several studies about the cost efficiency of the Czech and Slovak banking sectors but they are all related to the beginning of 2000 s, only.

\subsection{Determinants of banking efficiency}

Empirical studies on the determinants of banking efficiency consider bank-specific factors, industry-specific factors and macroeconomics factors. As showed by $\mathrm{Vu}$ - Nahm (2013), the bank-specific characteristics include bank size, equity over total assets, return on assets or equity, loans-to-total assets, type of ownership and bank capitalization.

Bank size is generally measured by its amount of assets. For example, Mercan et al. (2003), Williams - Nguyen (2005), Rezitis (2007) and Vu - Nahm (2013) found a positive relationship between bank size and efficiency. On the other hand, Is1k - Hassan (2002) and Chen et al. (2005) discovered a negative effect of bank size on efficiency. They found that small banks were more efficient than large banks. Řepková (2013) found that the highest average cost efficiency was achieved by the group of the medium-sized banks followed by the group of small banks in the Czech banking sector. The largest banks were the least efficient.

Level of capitalization was also found as an important determinant of banking efficiency. Altunbas et al. (2007), Chortareas et al. (2009) and Vu - Nahm (2013) 
found a positive relationship between the level of capitalization and banking efficiency. Palečková (2015) showed that the level of capitalization had a statistically significant positive impact on technical efficiency in the Czech banking sector. In contrast, according to Cavallo - Rossi (2002), the capitalization level had a negative impact on efficiency in the banking sector of Europe.

$\mathrm{As} \mathrm{Vu}$ - Nahm (2013) showed, some studies considered the influences of various types of risk, such as liquidity risk, credit risk and management risk. BergerMester (1997) found that banks with a higher ratio of loans to total assets (proxy for credit risk) were more profit efficient than other banks in the US banking sector. Yildirim - Philippatos (2007) also found a positive relationship between the ratio of loans to total asset and efficiency. In contrast, Brissimis et al. (2008) and Havrylchyk (2006) showed that banks with less liquidity were more efficient, because they do not hold the liquid assets in balance sheet. This result was also confirmed by Palečková (2015), who estimated that the level of liquidity of banks positively influenced the technical efficiency in the Czech banking sector.

GDP and the inflation rate were used in many studies. Maudos et al. (2002), Hasan et al. (2009), Pančurová - Lyócsa (2013) and Vu - Nahm (2013) showed a positive relationship between GDP and banking efficiency. Although Pančurová - Lyócsa (2013) found a negative coefficient of GDP per capita in the CEE countries, it indicated that banks operating in more developed economies were less cost efficient. $\mathrm{Vu}$ - Nahm (2013) also found that a low-inflation rate provided a favourable environment for banks to improve their profitability. Pančurová Lyócsa (2013) estimated a negative relationship between inflation and cost efficiency in the CEE countries.

The literature review showed that there was no common consensus either about the factors of banking efficiency or the methods for estimating the banking efficiency.

\section{METHODOLOGY AND DATA}

The study of the efficient frontier was introduced by Farrell (1957), who defined a simple measurement of firm's efficiency. He suggested that efficiency of any firm consists of two parts, i.e. technical and allocative efficiency. Technical efficiency is a firm's ability to produce maximum output from a given set of inputs; and allocative efficiency means the ability of a firm to use these inputs in an optimal proportion with respect to their prices. It is clear that data on prices are necessary for measuring allocative efficiency and Farrell called it cost efficiency. Therefore, the allocative type of efficiency inevitably depends on the prices of production variables that the production units must face. It requires that the mixture of inputs 
relative to their procurement prices and outputs relative to their selling prices needs to be technically efficient (Bod'a 2016).

The DEA ${ }^{2}$ method utilises a mathematical programming technique that measures relative efficiency of the production units, which are described as a Decision Making Unit (DMU), in comparison with other similar DMUs, with the restriction that all DMUs lie at or below the level of efficiency (Seiford - Thrall 1990). In other words, the DEA analysis is a well-known approach to rank the performance of homogenous decision making units (Kresta - Tichý 2016). Efficient production units are able to use the optimum amount of inputs or produce an optimum amount of outputs. The DEA method can handle a large number of variables and relations and this approach relaxes the requirements that are often encountered when one is limited to choosing only a few inputs and outputs because the techniques employed will otherwise encounter difficulties (Cooper et al. 2007). Due to these reasons, I measure cost efficiency using the DEA method.

Farrell (1957) proposed a measurement of cost efficiency, which assumes that prices are fixed and known, although they may possibly be different between the DMUs. He refers to it as a measurement of price efficiency but the more commonly used term is allocative efficiency. Methodology used in this paper followed the study of Cooper et al. (2007).

In order to obtain a measurement of cost efficiency for DMUs with multiple inputs and outputs, the minimum cost for the production of a DMU's current outputs with existing input prices is obtained by solving the following linear problem, as first formulated by Fare et al. (1985). The minimal cost model is formulated as:

$$
\operatorname{Min} \sum_{i=1}^{m} p_{i j_{0}} x_{i}^{0}
$$

subject to

$$
\begin{gathered}
\sum_{j=1}^{n} x_{i j} \lambda_{j}=x_{i}^{0}, \quad i=1, \ldots, m, \\
\sum_{j=1}^{n} y_{i j} \lambda_{j} \geq y_{r j_{0}}, \quad r=1, \ldots, s, \\
\lambda_{j} \geq 0, \quad j=1, \ldots, n,
\end{gathered}
$$

2 The DEA method was first introduced by Charnes et al. (1978). They extended Farrell's (1957) work and succeeded in establishing DEA as a basic for efficiency analysis. Their study called it the CCR model, which assumes constant returns to scale (CRS). Banker et al. (1984) modified the CCR model introducing the variable returns to scale (VRS) and it is called the BCC model. The BCC model eliminates inefficiencies caused by inadequate size of production units. The assumption of VRS provides a measurement of pure technical efficiency, which is a measurement of technical efficiency devoid of effects of scale efficiency. 


$$
x_{i}^{0} \geq 0, \quad i=1, \ldots, m,
$$

where $p_{i j_{0}}$ is price of input $i$ for the $D M U_{j_{0}}$ under assessment. $x_{i}^{0}$ is a variable that (at the optimal solution) gives the amount of input $i i$ to be employed by $D M U_{j_{0}}$ in order to produce the current outputs at minimal cost, subject to the technological restrictions imposed by the existing production possibility set. Note that the model assumes that the input prices at each DMU are fixed and known, although they can differ between DMUs.

Cost efficiency (CE) is then obtained as the ratio of minimum cost with the current prices (i.e., the optimal solution to this model) to the current cost at $D M U_{j_{0}}$, as follows:

$$
C E_{j_{0}}=\frac{\sum_{i=1}^{m} p_{i j_{0}} x_{i}^{0^{*}}}{\sum_{i=1}^{m} p_{i j_{0}} x_{i j_{0}}},
$$

where $*$ indicates the optimality ${ }^{3}$.

Next, in the second stage of DEA I estimate the determinants of banking efficiency. There are a number of ways in which environmental variables can be included into the DEA analysis. Banker - Natarajan (2008) showed that in a typical two-stage study based on DEA, the relative productivity of each organization is evaluated in the first stage based on the data on input consumption and output production. The productivity score is then regressed on potential contextual factors in the second stage to identify the factors whose impact on productivity is statistically significant. The alternative second stage methods have included the use of the relative productivity score or its logarithmic transformation as the dependent variable in an ordinary least squares (OLS) or a Tobit regression.

A large number of empirical researches use the OLS (Yadav - Katib 2015) or Tobit regression in the second stage (e.g. Garza-García 2012). However, the DEA score achieved the value in range between 0 and $1(0<\mathrm{h} \leq 1)$, making the dependent variable a limited dependent variable. The Tobit model (Tobin 1958) is suggested as an appropriate multivariate statistical model in the second stage to consider the characteristics of the distribution of efficiency measure (Grosskopf 1996). On the other hand, McDonald (2009) argued that the use of Tobit regression is considered inappropriate in the second stage of DEA and the best that can be said for it is that Tobit estimates are often similar to OLS estimates. This was because technical efficiency is a fraction data and not generated by a censoring process. Therefore, he suggested the use of OLS as most appropriate.

More detailed methodology about cost efficiency is described by, for example, Cooper et al. (2007) and Camanho - Dyson (2005). 
Therefore, I use the panel data analysis of OLS model to estimate the determinants of cost efficiency of commercial banks. A panel data set is formulated from a sample containing $N$ cross-sectional units (i.e. commercial banks) that are observed at different $T$ time periods (Asteriou - Hall 2011). A simple linear model with one explanatory variable is given as:

$$
Y_{i t}=\alpha_{i}+\beta X_{i t}+u_{i t},
$$

where the variables $Y$ and $X$ have both $i$ and $t$ subscripts for $i=1,2, \ldots, N$ banks and $t=1,2, \ldots, T$ time periods. The coefficient $\alpha_{i}$ can differ for each bank in the sample.

In the fixed effects method the constant is treated as group (section)-specific, which means that the model allows for different constants for each group (section). The fixed effects estimator is also known as the least squares dummy variable estimator because it includes a dummy variable for each group (Asteriou Hall 2011). One of the assumptions of panel data analysis is its stationarity, which we test using unit root test ${ }^{4}$.

\subsection{Data and selection of variables}

My data set consists of 28 commercial banks; i.e. owing to the homogeneity of the data, in particular, 16 Czech and 12 Slovak banks. I do not include the specialised financial institutions, building societies, mortgage banks, foreign bank branches and other specialized institutions. These banks represent more than a $75 \%$ share of total assets of the banking industry in the Czech Republic as well as in Slovakia. The sample is representative, and thus, the results of the paper could be interpreted as results of the banking sectors. The data is obtained from the annual reports of the banks during the period of 2005-2015.

Several major approaches (intermediation approach, production approach and value added approach) were developed in the empirical literature which define the relationship of inputs and outputs in the behaviour of financial institutions. The intermediation approach was introduced by Sealey - Lindley (1977), which suggests that the main purpose of banks is to transform their deposits into loans. Under production approach banks are characterised as service producers aiming at minimizing operating costs (Ahn - Le 2014). The modification of production approach is the user costs approach developed by Hancock $(1985,1986$ and

$4 \quad$ One of the first panel unit-root tests was developed by Levin - Lin (1992) and their work was finally published in Levin et al. (2002). More detailed information about panel unit root test is described in Asteriou - Hall (2011). 
1991). As shown by Bod'a - Zimková (2015), deposits are specified as both inputs and outputs of the cost/profit function of a bank. Hancock (1991) specified that demand deposits would be classified as outputs, while time deposits would be classified as inputs. The value-added approach considers that all liability and asset categories have some output characteristics. The categories having substantial value added are employed as important outputs, and others are treated as mainly unimportant outputs, intermediate products, or inputs, depending on the specifics of the category.

Berger - Humphrey (1997) stated that the intermediation approach may be more appropriate for evaluating entire financial institutions because this approach is inclusive of interest expenses, which often account for one-half to two-thirds of the total costs. Further, Tortosa-Ausina (2002) stated that the intermediation approach is considered to be more relevant for the banking sector, where the largest share of activity consists of the transformation of funds raised (deposits) to loans or investments. Thus, the intermediation approach is adopted for the analysis of cost efficiency in the Czech and Slovak commercial banks. This approach assumes that the commercial bank collects deposits and transforms them into loans.

I employed three inputs and their prices and one output with its price. In line with the intermediation approach, as inputs I chose deposits, fixed assets and the number of employees. The price of deposits is interest expenses, the price of fixed assets is other operating expenses and the price of the number of employees is personal expenses. As outputs I chose total loans and its price was interest income. Table 1 summarizes the selection of individual variables (inputs and outputs) and their prices. All data are reported in euro (EUR). The data are adjusted for inflation using GDP deflators. The values of GDP deflators were obtained from the World Bank Database. As Pančurová - Lyócsa (2013) stated, these adjustments were performed to increase data comparability.

Before using the data set for estimation of banking efficiency, several assumptions for data should be tested. First, Golany - Roll (1989) established a rule of

Table 1. Selection of inputs and outputs

\begin{tabular}{ll}
\hline Variable & Price \\
\hline \multicolumn{2}{c}{ Inputs } \\
\hline Total deposits & Interest expenses \\
\hline Fixed assets & Other operating expenses \\
\hline Number of employees & Personal expenses \\
\hline \multicolumn{2}{c}{ Output } \\
\hline Total loans & Interest income \\
\hline
\end{tabular}

Source: Author's compilation. 
thumb that the number of units should be at least twice the number of inputs and outputs considered. Thus, the used number of inputs and outputs is in line with this rule. Second, I tested the data for the independence assumption using the correlation analysis. Titko et al. (2014) mentioned that the appropriate variables to be included in the DEA model need to be checked using the correlation coefficient. The results of the correlation coefficient between inputs and outputs show that there is no dependence between the individual variables. Thus, the selected input and output variables for efficiency evaluations are appropriate. Third, I also test the separability assumption using regression-based tests according to Ruggiero (2005), who suggested a variable selection approach in which an initial measurement of efficiency is obtained from a set of known production variables. The results of the regression model show that all variables are significant with an adequate coefficient value. Thus, all variables in the analysis are relevant and the results of efficiency could be explained. Descriptive statistics of inputs and outputs are presented in Table 2.

Table 2. Descriptive statistics of inputs and outputs (thousand EUR)

\begin{tabular}{l|r|r|r|r|r}
\hline Variable & \multicolumn{1}{|c|}{ Mean } & \multicolumn{1}{c|}{ Median } & \multicolumn{1}{c|}{ Min. } & \multicolumn{1}{c|}{ Max. } & \multicolumn{1}{c}{ St. Dev. } \\
\hline Deposits & 5350579 & 2226552 & 4276 & 27870652 & 6796592 \\
\hline Fixed assets & 76183 & 27859 & 80 & 559334 & 115233 \\
\hline Loans & 3580139 & 1582396 & 1 & 17715009 & 4271892 \\
\hline Interest income & 195473 & 94000 & 1 & 1083226 & 225631 \\
\hline Interest expenses & 63203 & 27866 & 99 & 751997 & 101101 \\
\hline Personal expenses & 63205 & 24904 & 673 & 310755 & 76102 \\
\hline Other operating expenses & 84369 & 33530 & 644 & 431055 & 98014 \\
\hline Number of employees & 2284 & 825 & 25 & 10689 & 2781 \\
\hline
\end{tabular}

Source: Author's compilation.

In the second step, I examine the determinants of cost efficiency. I selected several factors which can influence the cost efficiency, such as bank size, capitalization level, credit and liquidity risk, profitability, riskiness of the bank's overall portfolio, GDP per capita and inflation rate. Bank size is represented by the amount of total assets. Capitalization level (CAP) is the ratio of equity to total assets. The ratio of total loans to total assets was used as a proxy for credit risk. Liquidity risk is represented by the ratio of total loans to total deposits. Profitability of banks is represented by the net interest margin (NIM) and return on average assets (ROAA). NIM provides a measure of asset productivity, therefore, it reflects both pricing policy and the available mix of assets and liabilities. NIM is calculated as a share of net interest income to total assets. ROAA measures the 
bank's ability to efficiently employ its assets and it is calculated as a share of net incomes to average assets. Riskiness of the bank's overall portfolio is computed as a ratio of loans loss provision to total assets. GDP presents the gross domestic product per capita in each country. The inflation rate is consumer prices as average percentage year-on-year. The descriptive statistics of the selected variables as determinants of efficiency are described in Table 3.

Table 3. Descriptive statistics of efficiency determinants (thousand EUR)

\begin{tabular}{l|r|r|r|r|r}
\hline Variable & \multicolumn{1}{|c|}{ Mean } & Median & \multicolumn{1}{c|}{ Min. } & \multicolumn{1}{c}{ Max. } & St. Dev. \\
\hline Bank size & 7066060 & 3052651 & 26705 & 35505073 & 8897121 \\
\hline Credit risk & 0.56 & 0.57 & 0.00 & 0.92 & 0.17 \\
\hline Liquidity risk & 0.71 & 0.74 & 0.00 & 1.52 & 0.22 \\
\hline Capitalization & 9.40 & 8.44 & 0.02 & 82.34 & 9.27 \\
\hline NIM & 3.13 & 2.93 & 0.39 & 8.86 & 1.34 \\
\hline ROAA & 0.65 & 0.89 & 3.71 & -8.41 & 1.52 \\
\hline Riskiness & 0.01 & 0.00 & 0.00 & 0.04 & 0.01 \\
\hline GDP & 15155 & 14963 & 11644 & 20000 & 1953 \\
\hline Inflation rate & 2.23 & 1.90 & -0.30 & 6.30 & 1.59 \\
\hline
\end{tabular}

Source: Author's compilation.

\section{EMPIRICAL ANALYSIS AND RESULTS}

I employed the DEA approach to estimate the relative cost efficiency of commercial banks in the two countries. For the empirical analysis I used the MaxDEA Pro 6.7 software. I estimated cost efficiency using the input-oriented model with variable returns to scale (BCC model). The CRS assumption is only justifiable when all DMUs are operating at an optimal scale. However, firms or DMUs in practice might face either economies or diseconomies to scale. Further, I used unbalanced panel data for analysis. The estimated efficiency of the Czech and Slovak banking sector are presented together and also individually for better lucidity. It is necessary to mention that I calculate relative cost efficiency. Table 4 presents the descriptive statistics of cost efficiency and Tables 5 and 6 provide the statistics of cost efficiency of the individual Czech and Slovak banks, respectively, over the period of 2005-2015.

The results in Table 4 show that the development of the average cost efficiency remains almost constant with a slight increase during the analysed period. Efficiency is in the range from 0 to 1 , respectively, from 0 to $100 \%$. The efficiency score of $100 \%$ means that the DMU operates on the $100 \%$ efficient frontier. The average efficiency was in a range of $69-84 \%$. The standard deviation is about 
Table 4. Descriptive statistics of average cost efficiency of the Czech and Slovak commercial banks, \%

\begin{tabular}{l|r|r|r|r|r|r|r|r|r|r|r}
\hline DMU & 2005 & 2006 & 2007 & 2008 & 2009 & 2010 & 2011 & 2012 & 2013 & 2014 & 2015 \\
\hline Mean & 0.69 & 0.68 & 0.69 & 0.71 & 0.82 & 0.79 & 0.81 & 0.80 & 0.84 & 0.80 & 0.80 \\
\hline Median & 0.61 & 0.67 & 0.68 & 0.73 & 0.89 & 0.82 & 0.90 & 0.92 & 0.95 & 0.90 & 0.89 \\
\hline Minimum & 0.33 & 0.33 & 0.27 & 0.22 & 0.40 & 0.40 & 0.41 & 0.41 & 0.41 & 0.29 & 0.25 \\
\hline Maximum & 1 & 1 & 1 & 1 & 1 & 1 & 1 & 1 & 1 & 1 & 1 \\
\hline St.Dev. & 0.20 & 0.21 & 0.22 & 0.23 & 0.20 & 0.19 & 0.21 & 0.21 & 0.19 & 0.22 & 0.24 \\
\hline
\end{tabular}

Source: Author's calculation.

$20 \%$, it means that there are differences between cost efficiencies of commercial banks. Next, I calculate cost efficiency of individual banks in the Czech Republic and Slovakia.

The results in Table 5 show that the most efficient banks were Česká sporitelna and Evropsko-ruská banka that operate on the 100\% efficient frontier. Česká sporitelna belongs to the group of the largest banks in the Czech banking industry. Fio banka, Evropsko-ruská banka and Air Bank are relatively new banks and the first two have operated in the sector since 2009 and Air Bank has started in 2011.

Table 5. Cost efficiency of the Czech commercial banks, \%

\begin{tabular}{l|c|c|c|c|c|c|c|c|c|c|c}
\hline DMU & 2005 & 2006 & 2007 & 2008 & 2009 & 2010 & 2011 & 2012 & 2013 & 2014 & 2015 \\
\hline Air Bank & & & & & & & 0.63 & 0.41 & 0.56 & 0.48 & 0.30 \\
\hline Ceská sporitelna & 1.00 & 1.00 & 1.00 & 1.00 & 1.00 & 1.00 & 1.00 & 1.00 & 1.00 & 1.00 & 1.00 \\
\hline CitiBank & 0.53 & 0.38 & 0.33 & & & & & & & & \\
\hline CSOB & 0.53 & 0.73 & 0.64 & 0.51 & 0.40 & 0.40 & 0.47 & 0.54 & 0.82 & 0.94 & 1.00 \\
\hline eBanka & 0.59 & 0.49 & 0.42 & & & & & & & & \\
\hline Equa bank & 1.00 & 1.00 & 1.00 & 1.00 & 0.96 & 0.74 & 0.89 & 0.95 & 0.99 & 0.93 & 0.73 \\
\hline Evropsko-ruská banka & & & & & 1.00 & 1.00 & 1.00 & 1.00 & 1.00 & 1.00 & \\
\hline Expobank & 0.61 & 0.64 & 0.80 & 0.75 & 0.77 & 0.83 & 0.86 & 0.94 & 0.99 & 0.90 & 1.00 \\
\hline Fio banka & & & & & & 0.68 & 0.53 & 0.48 & 0.52 & 0.39 & 0.25 \\
\hline JT Banka & 0.83 & 0.77 & 0.73 & 0.74 & 0.70 & 0.69 & 0.59 & 0.57 & 0.60 & 0.58 & 0.54 \\
\hline Komercni banka & 0.75 & 0.85 & 0.79 & 0.91 & 0.92 & 1.00 & 1.00 & 1.00 & 1.00 & 0.95 & 0.96 \\
\hline MONETA Money & 1.00 & 1.00 & 1.00 & 1.00 & 1.00 & 0.90 & 0.93 & 1.00 & 1.00 & 0.58 & 1.00 \\
\hline PPF banka & 0.45 & 0.39 & 0.27 & 0.22 & 0.50 & 0.54 & 0.48 & 0.48 & 0.41 & 0.29 & 0.32 \\
\hline Raiffesenbank & 0.72 & 0.88 & 1.00 & 0.97 & 1.00 & 1.00 & 1.00 & 1.00 & 1.00 & 1.00 & 0.97 \\
\hline Sberbank & 0.97 & 0.93 & 0.89 & 0.88 & 1.00 & 1.00 & 0.99 & 0.93 & 0.95 & 1.00 & 0.74 \\
\hline UniCredit Bank & 1.00 & 1.00 & 0.97 & 1.00 & 1.00 & 0.95 & 0.95 & 0.90 & 1.00 & 1.00 & 0.96 \\
\hline Mean & 0.74 & 0.74 & 0.73 & 0.78 & 0.87 & 0.82 & 0.83 & 0.82 & 0.85 & 0.80 & 0.75 \\
\hline Median & 0.72 & 0.77 & 0.79 & 0.88 & 0.97 & 0.87 & 0.94 & 0.94 & 0.99 & 0.94 & 0.96 \\
\hline St.Dev. & 0.21 & 0.23 & 0.27 & 0.25 & 0.21 & 0.20 & 0.22 & 0.24 & 0.22 & 0.26 & 0.30 \\
\hline
\end{tabular}

Source: Author's calculation. 
PPF banka, Fio Banka and Air Bank were the lowest efficient banks in the sector. PPF banka reached the average cost efficiency of $40 \%$, which means that $60 \%$ of costs are not used to produce outputs. This bank does not use the cost of inputs inappropriately. Also CitiBank and eBanka were low efficient banks, CitiBank is a branch of a foreign bank and eBanka has merged with Raiffesenbank in 2008.

One of the main advantages of the DEA model is that this model can explain the reasons of inefficiency for a DMU, i.e. a bank. I estimated the input-oriented model to analyze the reason of inefficiency in inputs. In all inefficient banks the main reason of inefficiency is the excess of clients' deposits in the banks' balance sheet. The DEA model shows the optimal value of inputs for each inefficient bank to be efficient. Another reason of inefficiency is the number of employees and the high value of cost of fixed assets in Expobank or in Air Bank.

The average value of cost efficiency of the Slovak commercial banks is reported in Table 6. In the Slovak banking sector, Všeobecná úverová banka (VUB) operated on the $100 \%$ efficient frontier during the periods of 2011-2012 and 2014-2015 and UniCredit Bank operated on the efficiency frontier in 2011. Analyzing the average cost efficiency I found that the most efficient banks were OTP

Table 6. Cost efficiency of the Slovak commercial banks, \%

\begin{tabular}{l|c|c|c|c|c|c|c|c|c|c|c}
\hline DMU & 2005 & 2006 & 2007 & 2008 & 2009 & 2010 & 2011 & 2012 & 2013 & 2014 & 2015 \\
\hline CitiBank & 0.60 & 0.44 & 0.55 & 0.35 & 0.59 & & & & & & \\
\hline CSOB & 0.47 & 0.67 & 0.68 & 0.56 & 0.84 & 0.77 & 0.87 & 0.84 & 0.86 & 0.83 & 0.87 \\
\hline Istrobanka & 0.71 & 0.66 & 0.61 & 0.72 & & & & & & & \\
\hline OTP Bank & 0.92 & 0.69 & 0.69 & 0.84 & 0.88 & 0.91 & 0.98 & 0.92 & 0.95 & 0.86 & 0.85 \\
\hline Postova banka & 0.33 & 0.33 & 0.29 & 0.38 & 0.41 & 0.48 & 0.51 & 0.61 & 0.60 & 0.58 & 0.59 \\
\hline Primabanka & 0.59 & 0.52 & 0.50 & 0.60 & 0.77 & 0.78 & 0.78 & 0.69 & 0.79 & 0.77 & 0.84 \\
\hline Privatbanka & & & & & & 0.43 & 0.41 & 0.42 & 0.59 & 0.58 & 0.96 \\
\hline Sberbank & 0.66 & 0.62 & 0.67 & 0.64 & 0.80 & 0.93 & 0.92 & 0.93 & 0.97 & 0.97 & 0.78 \\
\hline Slovenska sporitelna & 0.52 & 0.63 & 0.68 & 0.55 & 0.66 & 0.60 & 0.70 & 0.77 & 0.85 & 0.82 & 0.91 \\
\hline Tatrabanka & 0.61 & 0.73 & 0.79 & 0.75 & 0.90 & 0.82 & 0.94 & 0.93 & 0.92 & 0.94 & 0.95 \\
\hline UniCredit Bank & 0.54 & 0.53 & 0.56 & 0.54 & 0.98 & 0.78 & 1.00 & 0.95 & & & \\
\hline VUB & 0.57 & 0.54 & 0.62 & 0.69 & 0.91 & 0.87 & 1.00 & 1.00 & 0.98 & 1.00 & 1.00 \\
\hline Mean & 0.59 & 0.58 & 0.60 & 0.60 & 0.77 & 0.74 & 0.81 & 0.81 & 0.84 & 0.82 & 0.86 \\
\hline Median & 0.59 & 0.62 & 0.62 & 0.60 & 0.82 & 0.78 & 0.89 & 0.88 & 0.86 & 0.83 & 0.87 \\
\hline St.Dev. & 0.15 & 0.12 & 0.13 & 0.15 & 0.17 & 0.18 & 0.21 & 0.18 & 0.15 & 0.16 & 0.12 \\
\hline Sorce A & & & & & & &
\end{tabular}

Source: Author's calculation. 
Bank, Tatrabanka and VUB with the average cost efficiency over $80 \%$. Tatrabanka and VUB belong to the group of the largest banks in the industry. Also, Zimková - Bod'a (2015) found that these two largest Slovak commercial banks were the most cost efficient. The less efficient banks were Postova banka and Privatbanka. Postova banka reached the average cost efficiency below 50\%. It means that these banks could use only $50 \%$ of actual cost to produce outputs. The reason of inefficiency for these banks is also the excess of clients' deposits in the banks' balance sheet.

When I compared the average cost efficiency of the Czech and Slovak commercial banks, I found that the Czech banks were more efficient. The average median value was also higher in the Czech commercial banks than in Slovakia. In the Slovak banking sector, there were lower differences between cost efficiency of commercial banks than in the Czech banking sector. Also, the number of banks in the Slovak banking sector was lower than in the Czech banking industry. Other differences were the size of the banking industry, the Slovak banking sector registered lower degree of financial intermediation as well as value of total assets than the Czech banking sector. The Czech commercial banks can use their inputs better to produce outputs as well as the price of the inputs and outputs were better used. The average value of efficiency of the Czech banking sector is found in the range of $73-85 \%$. The average value of the Slovak banking sector reached the value of $59-86 \%$. Thus, I found only marginal differences in efficiency in the Czech banking sector. I confirmed the results of Pančurová - Lyócsa (2013) and Kočišová (2015) who found that the Czech banking sector is more cost efficient than the Slovak banking sector.

In the second stage of the DEA model to estimate the determinants of cost efficiency of the banking sectors I employed the panel data analysis method. Using equation (8) I estimate individual determinants of cost efficiency by using the equation:

$$
\begin{aligned}
\ln C E F_{i t}= & \alpha_{i t}+\beta_{1} \ln C A P_{i t}+\beta_{2} \ln G D P_{t}+\beta_{3} \ln I R_{t}+\beta_{4} \ln L R_{i t}+\beta_{5} \ln N I M_{i t} \\
& +\beta_{6} \ln R O A A_{i t}+\beta_{7} \ln R I S K I N E S S_{i t}+\beta_{8} \ln B S_{i t}+u_{i t},
\end{aligned}
$$

where the dependent variable $C E F$ is cost efficiency of the bank estimated from the DEA model, $C A P$ is bank capitalization, GDP denotes GDP per capita, $I R$ is the inflation rate, $L R$ is liquidity risk, NIM presents net interest income, ROAA is return on average assets, RISKINESS is riskiness of the overall portfolio of the bank and $B S$ is bank size, $i$ denotes the bank $(i=1, \ldots, N)$ and $t$ denotes time $(t=1, \ldots, T)$.

The assumption of the panel data analysis is based on using the stationary data. Thus, it is necessary to test stationarity of the time series. I used the Levin, Lin and Chu test for the individual variables to examine the existence of the unit 
roots. The result of the test indicates that the variables are stationary in the values at a significance level at $1 \%$ so that the null hypothesis of a unit root can be rejected for any of the series (Appendix 1). Thus all variables are stationary and can be used in the panel regression analysis. I estimated Equation (8) by using the OLS method. For the panel data analysis I also tested the co-integration of these variables using Kao co-integration test and found the presence of co-integration. The results are presented in Appendix 2. As the data were co-integrated I used it for panel data analysis. Next, I tested for heteroscedasticity (Appendix 3 ) and its presence is rejected, therefore the error term is considered to be homoscedastic. For detecting multicollinearity I used the correlation coefficient. From the correlation matrix in Appendix 4, it becomes obvious that the credit risk and total liquidity risk are positively correlated. Thus, I removed the variable credit risk from the final model. I found normality of the error term. The absence of autocorrelation of the error term is determined by using the Durbin-Watson test. To allow for heterogeneity across the banks, I use an error-component model estimated as fixed effects. Testing for fixed effect rejects the null hypothesis that fixed effects are redundant, therefore fixed effects are considered to be suitable for this analysis (Appendix 5). As a dependent variable I used cost efficiency; moreover as independent variables I used bank-specific and macroeconomic indicators. The final result of the panel data analysis is presented in Table 7.

The results of the panel data model show that liquidity, GDP per capita and bank size positively influence cost efficiency. This means that larger banks were more cost efficient. This finding is in line with the result of Zimková - Bod'a (2015), who found that the most cost efficient were the large Slovak commercial banks. Although the coefficient of banks' size is very low, the impact of banks' size is

Table 7. Determinants of banking efficiency

\begin{tabular}{l|c|c}
\hline Variable & Coefficient & Std. Error \\
\hline Constant & $0.5758^{*}$ & 0.0891 \\
\hline Capitalization & -0.0030 & 0.0027 \\
\hline GDP & $0.0001^{*}$ & 0.0000 \\
\hline Inflation rate & $-0.0051^{* * *}$ & 0.0033 \\
\hline Liquidity risk & $0.6910^{*}$ & 0.0600 \\
\hline NIM & $-0.0199^{* * *}$ & 0.0135 \\
\hline ROAA & -0.0048 & 0.0057 \\
\hline Riskiness & 0.3460 & 0.8175 \\
\hline Bank size & $0.0001^{*}$ & 0.0000
\end{tabular}

Adjusted $\mathrm{R}^{2}=0.8746$, Prob(F-statistic) $=0.0000, \mathrm{DW}=1.96$

Note: * significance at $1 \%$ level, $* * *$ significance at $10 \%$ level.

Source: Author's calculation. 
not so clear. I also find that economic growth positively affects cost efficiency. This result supports the results of Maudos et al. (2002), Hasan et al. (2009) or Vu - Nahm (2013) who also found a positive relationship between GDP and banking efficiency. Also banks with low liquidity have more efficiency, and it is caused by the fact that banks do not hold liquid assets in the balance sheet. Thus these banks were more cost efficient. This finding is not surprising, because banks that hold less liquid assets can invest and lend more, and this increases banks' output. These findings are in line with the results of DEA model. The model shows that the reason of inefficiency was the excess of client's deposits in the balance sheet. Commercial banks cannot be exposed to excessive liquidity risk that threatens their stability. Banks should find a balance between risks and efficiency.

However, the surprising findings are that the net interest margin has a negative impact on cost efficiency, which implies that the more profitable banks are less cost efficient. These results should probably be explained by the fact that more profitable banks do not use the price of inputs in optimal proportion to produce their outputs. I can conclude that profitable banks must not be cost efficient. Thus, banks that are profitable should also consider the prices of inputs and outputs. Further, the inflation rate also negatively influences cost efficiency. This finding is in line with the theory and shows that a low-inflation rate leads to a higher cost efficiency of banks. Also, Pančurová - Lyócsa (2013) claim that this relationship supports the general view that inflation hinders creditor institutions.

The results of the empirical analysis show that level of capitalization, ROAA and riskiness of banking portfolio have no statistically significant impact on cost efficiency of the commercial banks. Although I find a positive relationship between loan losses and efficiency, this relationship is not statistically significant. Nevertheless, the positive relationship is possible, at least in the short-run, if some banks prefer not to spend sufficient resources to review loan applications and as a result, these banks appear to be efficient. Thus, I can conclude that the Czech and Slovak commercial banks with less liquidity were more cost efficient. Moreover, the banks were found to be more cost efficient when economy was in expansion with a lower inflation rate.

\section{CONCLUSIONS}

The aim of this paper was to estimate cost efficiency and its determinants of the Czech and Slovak commercial banks in the period of 2005-2015. I find that the development of cost efficiency was almost constant during the analyzed period. The Czech banks were more cost efficient than the Slovak ones and more Czech banks operated on the efficiency frontier than the banks in Slovakia. The average 
median value was also higher in the Czech commercial banks than in the Slovak banks. In the Slovak banking sector there were lower differences between cost efficiency of individual banks than in the Czech banking sector. Further, only marginal differences in cost efficiency are found in the Czech and Slovak banking sectors.

I also estimated the determinants of cost efficiency of the commercial banks in the two countries, using the panel data analysis and found that the bank-specific factors, as well as the macroeconomic factors, haved affected the cost efficiency.

In terms of asset size, cost inefficiency with bank size. It was observed that size could be an advantage when it comes to adopting the regulatory reforms, i.e., it is possible that large banks are enjoying more benefits than small ones from the regulatory changes. Also, banks with low liquidity were more efficient. It means that banks with higher liquidity risks are more cost efficient, but banks should be stable. Thus, the purpose of risk management is to manage liquidity risks and find a balance between degree of risk and banking efficiency. The results also show that profitability negatively influences cost efficiency, thus profitable banks are less efficient than others. The higher economic growth positively affects cost efficiency and also a low inflation rate leads to higher cost efficiency of banks. On the other hand, capitalization level and riskiness of banking portfolio do not have statistically significant impact on cost efficiency.

The results of this study also show that banks with lower liquidity and profitability are more efficient. However, banks also should consider liquidity, credit and operation risks and profitability to manage cost efficiency. The recommendation is that profitable banks should also analyze the structure of price of inputs. Moreover, these findings suggest that the efficiency of several commercial banks was not optimal, indicating the potential for significant improvements in cost efficiency. From a policy perspective, these findings suggest that the supervision of commercial banking system in the Czech Republic and Slovakia could be strengthened by putting an emphasis on the cost efficiency, at least as the standard ratios as indicators of bank performance. The lower value of efficiency could indicate a problem with stability and efficiency of the financial system, as well as the economy. Moreover, the link between bank risk (namely liquidity risk) and efficiency should be considered.

This research highlights the importance of encouraging increased efficiency by focusing on bank-specific factors. Moreover, since banks with less liquid risk were more efficient, the risk measure should be properly incorporated in banking supervision and regulation. The managers of the banks can focus on risk management. Furthermore, this implies that the challenge for policymakers is to provide a framework which encourages efficiency and competition while avoiding excessive risk-taking. 
Further research should analyze the reasons of the negative impact of profitability on cost efficiency. I find that there is no consensus in the literature about the most appropriate method for estimation of banking efficiency determinants, in further research I would like to apply the bootstrap method and compare the results.

\section{REFERENCES}

Ahn, H. - Le, M. H. (2014): An Insight into the Specification of the Input-Output Set for DEABased Bank Efficiency Measurement. Management Review Quarterly, 64(1): 3-37.

Aliu, Fl. - Krasniqi, B. - Knapkova, A. - Fisnik Aliu, Fi: (2019): Interdependence and Risk Comparison of Slovak, Hungarian and Polish Stock Market: Policy and Managerial Implications. Acta Oeconomica, 69(2): 273-288.

Altunbas, Y. - Carbo, S. - Gardener, E. P. M. - Molynuex, P. (2007): Examining the Relationship between Capital, Risk and Efficiency in European Banking. European Financial Management, 13(1): 49-70.

Andries, A. M. - Căpraru, B. (2011): Bank Performance in Central and Eastern Europe: The Role of Financial Liberalization. European Financial Management Association, Braga.

Ariff, M. - Can, L. (2008): Cost and Profit Efficiency of Chinese Banks: A Non-Parametric Analysis. China Economic Review, 19: 260-273.

Asteriou, D. - Hall, S. G. (2011): Applied Econometrics. New York: Palgrave Macmillan.

Banker, R. D. - Natarajan, R. (2008): Evaluating Contextual Variables Affecting Productivity. Operations Research, 56: 48-58.

Berger, A. N. - Humphrey, D. (1997): Efficiency of Financial Institutions: International Survey and Directions for Future Research. European Journal of Operational Research, 98: 175-212.

Berger, A. N. - Mester, L. J. (1997): Inside the Black Box: What Explains Differences in the Efficiencies of Financial Institutions? Journal of Banking and Finance, 21(7): 895-947.

Bod'a, M. (2016): Selected Methodological Issues in Technical Efficiency Measurement of Banks Branches. Bratislava: Wolters Kluwer.

Bod'a, M. - Zimková, E. (2015): Efficiency in the Slovak Banking Industry: A Comparison of Three Approaches. Prague Economic Papers, 24(4): 434-451.

Brissimis, S. N. - Delis, M. D. - Papanikolaou, N. I. (2008): Exploring the Nexus between Banking Sector Reform and Performance: Evidence from Newly Acceded EU Countries. Journal of Banking and Finance, 32(12): 2674-2683.

Camanho, A. - Dysons, R. G. (2005): Cost Efficiency Measurement with Price Uncertainty: A DEA Application to Bank Branch Assessments. European Journal of Operational Research, 161: 432-446.

Casu, B. - Girardone, C. - Molyneux, P. (2004): Productivity Change in European Banking: A Comparision of Parametric and Non-Parametric Approaches. Journal of Banking and Finance, 28: 2521-2540.

Cavallo, L. - Rossi, S. P. S. (2002): Do Environmental Variables Affect the Performance and Technical Efficiency of European Banking Systems? A Parametric Analysis Using the Stochastic Frontier Approach. European Journal of Finance, 8: 123-146.

Charnes, A. - Cooper, W. W. - Rhodes, E. (1978): Measuring the Efficiency of Decision Making Units. European Journal of Operational Research, 2: 429-444. 
Chen, X. - Michael, S. - Brown, K. (2005): Banking Efficiency in China: Application of DEA to Pre- and Postderegulation Eras: 1993-2000. China Economic Review, 16: 229-245.

Chortareas, G. E. - Girardone, C. - Ventouri, A. (2009): Efficiency and Productivity of Greek Banks in the EMU Era. Applied Financial Economics, 19: 1317-1328.

Chronopoulos, D. K. - Girardone, C. - Nankervis, J. C. (2011): Are there any Cost and Profit Efficiency Gains in Financial Conglomeration? Evidence from the Accession Countries. The European Journal of Finance, 17(8): 603-621.

Cooper, W. W. - Seiford, L. M. - Tone, K. (2007): Data Envelopment Analysis: A Comprehensive Text with Models, Applications, References and DEA-Solver Software. 2nd ed. New York: Springer Science and Business Media.

Costa, da R. R. - Lagoa, S. (2018): Factors Affecting International Banking Financial Flows into a Peripheral Country of the Euro Area. Acta Oeconomica, 68(3): 353-376.

Fare, R. - Grosskopf, S. - Lovell, C. A. K. (1985): The Measurement of Efficiency of Production. Boston: Kluwer-Nijhoff.

Farrell, M. J. (1957): The Measurement of Productive Efficiency. Journal of the Royal Statistical Society (Series A), 120(2): 253-281.

Fries, S. - Taci, A. (2005): Cost Efficiency of Banks in Transition: Evidence from 289 Banks in 15 Post-Communist Countries. Journal of Banking and Finance, 29: 55-81.

Garza-García, J. G. (2012): Determinants of Bank Efficiency in Mexico: A Two-Stage Analysis. Applied Economics Letters, 19(17): 1679-1682.

Golany, B. - Roll, Y. (1989): An Application Procedure for DEA. Omega, 17: 237-250.

Hancock, D. (1985): The Financial Firm: Production with Monetary and Nonmonetary Goods. The Journal of Political Economy, 93(5): 859-880.

Hancock, D. (1986): A Model of the Financial Firm with Imperfect Asset and Deposit Elasticities. Journal of Banking and Finance, 10(1): 37-54.

Hancock, D. (1991): A Theory of Production for the Financial Firm. Norwell: Kluwer Academic Publishers.

Hasan, I. - Wachtel, P. - Zhou, M. (2009): Institutional Development, Financial Deepening and Economic Growth: Evidence from China. Journal of Banking and Finance, 33(1): 157-170.

Havrylchyk, O. (2006): Efficiency of the Polish Banking Industry: Foreign Versus Domestic Banks. Journal of Banking and Finance, 30(7): 1975-1996.

Hosszú, Zs. - Dancsik, B. (2018): Measuring Bank Efficiency and Market Power in the Houshold and Corporate Credit Markets Considering Market risks. Acta Oeconomica, 68(2): 175-207.

Irsova, Z. - Havranek, T. (2011): Bank Efficiency in Transitional Countries: Sensitivity to Stochastic Frontier Design. Transition Studies Review, 18(2): 230-270.

Isık, I. - Hassan, M. K. (2002): Technical, Scale and Allocative Efficiencies of Turkish Banking Industry. Journal of Banking and Finance, 26: 719-766.

Kočišová, K. (2014): Application of Data Envelopment Analysis to Measure Cost, Revenue and Profit Efficiency. Statistika, 94(3): 47-57.

Kočišová, K. (2015): Loan Efficiency in the Visegrad Countries. Acta Oeconomica, 65(S): 163183.

Kresta, A. - Tichý, T. (2016): Selection of Efficient Market Risk Models: Backtesting Results Evaluation with DEA Approach. Computers and Industrial Engineering, 102: 331-339.

Maudos, J. - Pastor, J. M. - Perez, F. - Quesada, J. (2002): Cost and Profit Efficiency in European Banks. Journal of International Financial Markets, Institutions and Money, 12(1): 33-58.

McDonald, J. (2009): Using Least Square and Tobit in Second Stage DEA Efficiency Analyses. European Journal of Operational Research, 197: 792-798. 
Mercan, M. - Arnold, R. - Reha, Y. - Ahmet, B. E. (2003): The Effect of Scale and Mode of Ownership on the Financial Performance of the Turkish Banking Sector: Results of a DEA-Based Analysis. Socio-Economic Planning Sciences, 37: 185-202.

Murillo-Zamorano, L. R. (2004): Economic Efficiency and Frontier Techniques. Journal of Economic Surveys, 18(1): 33-77.

Pančurová, D. - Lyócsa, Š. (2013): Determinants of Commercial Banks’ Efficiency: Evidence from 11 CEE Countries. Finance a úvěr - Czech Journal of Economics and Finance, 63(2): $152-179$.

Řepková, I. (2013): Cost and Profit Efficiency of the Czech Commercial Banks. International Journal of Mathematical Models and Methods in Applied Sciences, 7(3): 286-294.

Rezitis, N. A. (2007): Efficiency and Productivity Effects of Bank Mergers: Evidence from the Greek Banking Industry. Economic Modelling, 25: 236-254.

Rossi, S. - Schwaiger, M. - Winkler, G. (2005): Managerial Behavior and Cost/Profit Efficiency in the Banking Sectors of Central and Eastern European Countries. Working Paper, No. 96, Oesterreichische Nationalbank.

Ruggiero, J. (2005): Impact Assessment of Input Omission on DEA. International Journal of Information Technology and Decision Making, 4(3): 359-368.

Sealey, C. W. - Lindley, J. T. (1977): Inputs, Outputs and a Theory of Production and Cost at Depository Financial Institutions. Journal of Finance, 32(8): 1251-1266.

Seiford, L. M. - Thrall, R. M. (1990): Recent Developments in DEA: The Mathematical Programming Approach to Frontier Analysis. Journal of Econometrics, 46: 7-38.

Staněk, R. (2010): Efektivnost českého bankovního sektoru v letech 2000-2009 (Efficiency of the Czech banking sector in the period 2000-2009). Konkurenceschopnost a stabilita, Brno: Masaryk University, pp. 81-89.

Stavárek, D. - Polouček, S. (2004): Efficiency and Profitability in the Banking Sector. In: Polouček, S. (ed.): Reforming the Financial Sector in Central European Countries. Houndmills: Palgrave Macmillan, pp. 75-135.

Titko, J. - Stankevičienė, J. - Lāce, N. (2014): Measuring Bank Efficiency: DEA Application. Technological and Economic Development of Economy, 20(4): 739-757.

Tortosa-Ausina, E. (2002): Financial Costs, Operating Costs, and Specialization of Spanish Banking Firms as Distribution Dynamics. Applied Economics, Taylor and Francis Journals, 34(17): $2165-2176$.

Vu, H. - Nahm, D. (2013): The Determinants of Profit Efficiency of Banks in Vietnam. Journal of the Asia Pacific Economy, 18: 615-631.

Weill, L. (2007): Is there a Gap in Bank Efficiency between CEE and Western European Countries? Comparative Economic Studies, 47: 101-127.

Williams, J. - Nguyen, N. (2005): Financial Liberalisation, Crisis, and Restructuring: A Comparative Study of Bank Performance and Bank Governance in South East Asia. Journal of Banking and Finance, 29(8-9): 2119-2154.

Yadav, R. - Katib, M. N. (2015): Technical Efficiency of Malaysia's Development Financial Institutions: Application of Two-Stage DEA Analysis. Asian Social Science, 11(16): 175-182.

Yildirim, H. S. - Philippatos, G. (2007): Efficiency of Banks: Recent Evidence from the Transition Economies of Europe, 1993-2000. The European Journal of Finance, 13: 123-143.

Zimková, E. (2015): Cost Efficiency of Slovak Commercial Banks under the Standpoint of the Intermediation Approach. In: Hronová, S. - Vltavská, K. (eds): Proceeding of the 18th AMSE Applications of Mathematics and Statistics in Economics. Prague: University of Economics.

Zimková, E. - Bod'a, M. (2015): Cost Efficiency of Slovak Commercial Banks under the Standpoint of the Production Approach. Presentation at the 9th International Days of Statistics and Economics. Prague: University of Economics. 


\section{APPENDIX}

Appendix 1. Unit root test (Levin, Lin and Chu test)

\begin{tabular}{l|c|c}
\hline & Statistic & Stationarity \\
\hline Efficiency & $-8.7238^{\mathrm{a}}$ & stationary \\
\hline Bank size & $-3.61545^{\mathrm{a}}$ & stationary \\
\hline Credit risk & $-11.0197^{\mathrm{a}}$ & stationary \\
\hline Liquidity risk & $-125.094^{\mathrm{a}}$ & stationary \\
\hline Capitalization & $-14.3321^{\mathrm{a}}$ & stationary \\
\hline NIM & $-11.7583^{\mathrm{a}}$ & stationary \\
\hline ROAA & $-17.0874^{\mathrm{a}}$ & stationary \\
\hline Riskiness & $-5.03204^{\mathrm{a}}$ & stationary \\
\hline GDP & $-7.0691^{\mathrm{a}}$ & stationary \\
\hline Inflation rate & $-10.3349^{\mathrm{a}}$ & stationary \\
\hline
\end{tabular}

Note: ${ }^{\mathrm{a}}$ significance at $1 \%$ level, ${ }^{\mathrm{b}}$ significance at $5 \%$ level, ${ }^{\mathrm{c}} \mathrm{s}$ significance at $10 \%$ level. Source: Author's calculation.

Appendix 2. Co-integration test

\begin{tabular}{l|c}
\hline & t-Statistic \\
\hline ADF & $-3.091086^{\mathrm{a}}$ \\
\hline Residual variance & 0.007508 \\
\hline HAC variance & 0.004667 \\
\hline
\end{tabular}

Note: ${ }^{\text {a }}$ significance at $1 \%$ level.

Source: Author's calculation.

Appendix 3. Heteroscedasticity test

\begin{tabular}{l|c|l|c}
\hline Adjusted R-squared & 0.131061 & Mean dependent var & 0.000189 \\
\hline S.E. of regression & 0.001245 & S.D. dependent var & 0.001336 \\
\hline Sum squared resid & 0.000339 & Akaike info criterion & -10.50065 \\
\hline Log likelihood & 1206.074 & Schwarz criterion & -10.36528 \\
\hline F-statistic & 0.6245 & Hannan - Quinn criter. & -10.44603 \\
\hline Prob(F-statistic) & 0.6812 & Durbin - Watson stat. & 2.005828 \\
\hline
\end{tabular}

Source: Author's calculation. 
Appendix 4. Correlation matrix

\begin{tabular}{l|c|c|c|c|c|c|c|c|c}
\hline Probability & Bank size & $\begin{array}{c}\text { Credit } \\
\text { risk }\end{array}$ & $\begin{array}{c}\text { Liquid- } \\
\text { ity risk }\end{array}$ & CAP & NIM & ROAA & $\begin{array}{c}\text { Riski- } \\
\text { ness }\end{array}$ & GDP & Inflation \\
\hline Bank size & 1.0000 & & & & & & & & \\
\hline Credit risk & $-0.2202^{\mathrm{a}}$ & 1.0000 & & & & & & & \\
\hline $\begin{array}{l}\text { Liquidity } \\
\text { risk }\end{array}$ & $-0.1604^{\mathrm{b}}$ & $0.9414^{\mathrm{a}}$ & 1.0000 & & & & & & \\
\hline CAP & 0.0113 & $0.1820^{\mathrm{a}}$ & $0.2483^{\mathrm{a}}$ & 1.0000 & & & & & \\
\hline NIM & 0.0348 & 0.0241 & 0.0157 & $0.3439^{\mathrm{a}}$ & 1.0000 & & & & \\
\hline ROAA & $0.3812^{\mathrm{a}}$ & $-0.1325^{\mathrm{b}}$ & -0.0811 & 0.0070 & $0.4079^{\mathrm{a}}$ & 1.0000 & & & \\
\hline Riskiness & $-0.1514^{\mathrm{b}}$ & 0.1070 & $0.1115^{\mathrm{c}}$ & $0.1678^{\mathrm{b}}$ & $0.4041^{\mathrm{a}}$ & $-0.1651^{\mathrm{b}}$ & 1.0000 & & \\
\hline GDP & 0.1090 & -0.0740 & -0.0504 & -0.0075 & -0.0642 & $0.1303^{\mathrm{c}}$ & $-0.1853^{\mathrm{a}}$ & 1.0000 & \\
\hline Inflation & -0.1004 & -0.1084 & -0.0745 & $-0.1231^{\mathrm{c}}$ & 0.0461 & -0.0330 & -0.0807 & $0.2087^{\mathrm{a}}$ & 1.0000 \\
\hline
\end{tabular}

Note: ${ }^{\mathrm{a}}$ significance at $1 \%$ level, ${ }^{\mathrm{b}}$ significance at $5 \%$ level, ${ }^{\mathrm{c}}$ significance at $10 \%$ level

Source: Author's calculation.

Appendix 5. Fixed effect test in Panel Data Analysis

\begin{tabular}{l|c|c}
\hline Effects Test & Statistic & d.f. \\
\hline Cross-section F & $6.224668^{\mathrm{a}}$ & $-25,194$ \\
\hline Cross-section Chi-square & $134.287262^{\mathrm{a}}$ & 25 \\
\hline
\end{tabular}

Note: ${ }^{\text {a }}$ denotes significance at $1 \%$ level.

Source: Author's calculation. 